\title{
Developing Alternative Mangrove Ecosystem Management Scenarios through Economic Valuation in the Coastal Area of Jangkaran Village, Kulon Progo Regency, Indonesia
}

\author{
Dwike Ariestantya ${ }^{1, *}$ and Rika Harini ${ }^{1}$ \\ ${ }^{1}$ Department of Environmental Geography, Faculty of Geography, Universitas Gadjah Mada, Sekip Utara, Bulaksumur, Yogyakarta 55281, \\ Indonesia \\ *Corresponding author: Dwike.Ariestantya@mail.ugm.ac.id
}

KEYWORDS

Aquaculture

Management

Mangrove

Prawn ponds

Priority scenario

\begin{abstract}
Mangrove ecosystems have multiple functions, including economic and environmental ones. For optimal benefits, mangrove ecosystem management should be well-proportioned. The purpose of this study was to determine the most appropriate scenario for managing a mangrove ecosystem alongside aquaculture ponds, by performing an economic valuation to find out the value of management with the most beneficial scenarios, both ecologically and economically. Data were collected through interviews using questionnaires, literature reviews, and institutional data. These data were then processed through economic valuations of the total economic value and cost-benefit analysis. Data were analysed spatially and descriptive-quantitatively. The total economic value of the mangrove ecosystem was USD 6.73 million. The benefit and costs of managing mangrove ecotourism were USD $3,930.74 / \mathrm{ha} /$ year and USD 1,701.69/ha/year, respectively, whereas the benefits and costs of managing ponds were USD 150,433.85/ha/year and USD 55,269.46/ha/year, respectively. The prioritized scenario of mangrove ecosystem management is one with an ideal proportion of mangrove and pond areas (i.e. 50:50) and the total ecological and economic benefits for a period of 25 years is USD 19.17 million.
\end{abstract}

(c) The Author(s) 2019. This article is distributed under a Creative Commons Attribution-ShareAlike 4.0 International license.

\section{INTRODUCTION}

Mangrove ecosystems provide many benefits for the environment and the surrounding community, both in the forms of use and non-use values. The ecological functions of a mangrove forest include those of a catalyst, nutrient producer, and carbon cycling agent, as a habitat, as a source of income-generating activities, a location for aquatic biota nursery, enlargement, and spawning, in protection against the threats of tsunamis and tidal waves, environmental conservation, and education. Meanwhile, the economic functions of mangrove forests include fulfilling household, agricultural, animal farming, and industrial needs, along with being a potential location for ecotourism activities (Murtini et al. 2018). The many benefits provided by mangrove ecosystems lead to various interests of many parties in utilizing them. The use of mangrove ecosystems often raise conflict of interests, which in turn lead to different types of management that are based on immature and unsustainable considerations.

The Special Region of Yogyakarta (DIY) is a province in Java with the smallest area of mangrove forest in Indonesia. Mangrove forest takes up only 40.10 hectares, mostly in damaged condition (Statistics Indonesia 2017), so that mangrove forests in DIY are categorized as rare and endangered. One of the mangrove ecosystems in DIY is located in Jangkaran Village, Kulon Progo Regency, where the mangroves grow at the mouth of the Bogowonto River, which includes two hamlets, Pasir Mendit and Pasir Kadilangu. The potential for mangrove growth in this river area is $95 \%$, while in the rear swamp area is $75 \%$, which means that, ecologically, this region does have the potential for developing mangrove ecosystems (Djohan 2000).

The environment around these mangrove ecosystems is also used for aquaculture activities, specifically prawn ponds, which are carried out relatively close to community settlements. These activities have damaged the mangrove forests, making mangrove conservation a critical agenda of the government and concerned parties since the 1990s. Rehabilitation efforts have had limited success, however, due to various social and ecological factors. In 2016, the mangrove ecosystem in Jangkaran Village also began to be developed for ecotourism activities, for which the management began to be more organized, but did not not rule out possible changes from happening again as long as the community are not aware of the importance of the existence of mangroves and their ecosystems (Statistics Indonesia 2017).

Mangrove ecosystems, especially in terms of the existence of mangroves themselves, can be developed not only for conservation and commercial purposes in the forms of forest conservation and ecotourism activities. With an appropriate, proportional management, they can also be developed simultaneously with aquaculture in the forms of ecotourism and aquaculture that are beneficial both economically (efficiency), socially (equality), and ecologically (sustainability) (Adrianto 2006). 
Mangrove ecosystem management can be planned side-by-side with that of aquaculture considering that the presence of mangroves can be used as a filter for waste resulting from pond business activities. Proportionally, the ratio of ponds and mangroves areas positively correlate with production level in that the higher the ratio of ponds and mangroves areas, the higher the pond production, which in turn increases income. The wider the mangrove area, the higher the income from commercial and ecotourism activities related to the mangrove ecosystem (Kridalaksana et al. 2014).

The purpose of this study was to determine the most profitable scenario of managing mangrove ecosystems alongside aquaculture. This was done by making economic valuations to find out the management values with different scenarios in order to identify the most profitable one. The calculations were based on the extent of each planned scenario. The management value was obtained from the benefits and costs analysis of each scenario.

\section{METHODS}

\subsection{Research location}

The research location was administratively located in the coastal area of Jangkaran Village, Kulon Progo Regency, Special Region of Yogyakarta, Java, Indonesia, at the coordinates of $49 \mathrm{M}$, which are between 390096-394703 mT and 9127955-9127733 mU or at $7^{\circ} 53.28-7^{\circ} 53.41$ ' South Latitude and $110^{\circ} 00.18-110^{\circ} 02.69^{\prime}$ East Longitude. The research location was purposefully determined based on the consideration that the coastal area of Jangkaran Village, especially the estuaries of the Bogowonto and Pasir Rivers, both of which are tributaries Bogowonto River, have mangrove ecosystems that need to be preserved. The existence of mangroves in this particular area can be said to be endangered because of overlapping interests, especially that of individual interests in the development of aquaculture, specifically prawn ponds (Figure 1).

The mangrove ecosystems in this coastal area are located in two hamlets, Pasir Mendit and Pasir Kadilangu. Mangrove cultivation efforts have been carried out since the 1990s but the success of these efforts has still been very limited. The limited success of mangrove cultivation is influenced by many factors, including physical factors such as ebb and flow patterns and length of inundation periods, as well as human factors as the most influential factors.

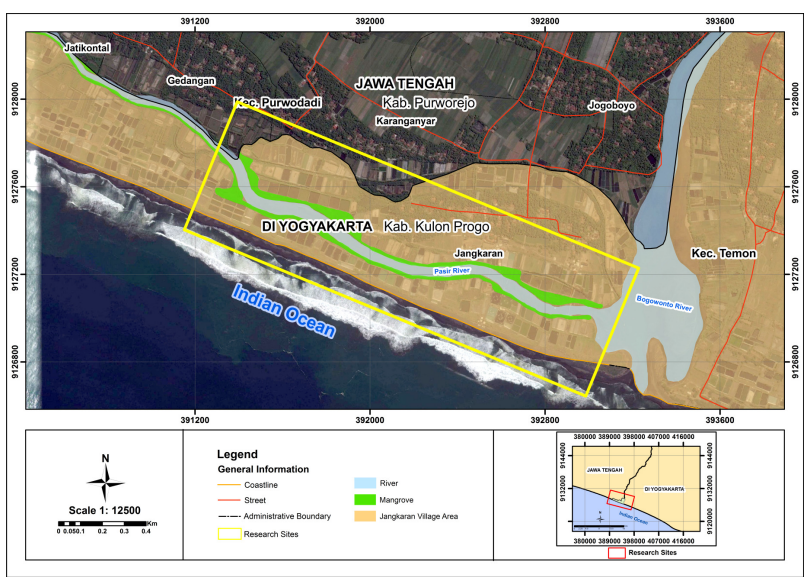

FIGURE 1. Map of mangrove distribution in the coastal area of Jangkaran Village, Kulon Progo Regency.
In 2003, it was identified that there had been a massive change in the mangrove ecosystems due to aquaculture developments (Figure 2). This indicates a lack of public awareness of the importance of mangrove ecosystems because many people view aquaculture mainly as a source of direct economic profit for them.

\subsection{Data collection and analysis}

The data collected in this study were quantitative, originating from two sources, namely secondary and primary data. The primary data included the results of interviews using questionnaires regarding the benefits of mangrove forest components and the cost and benefit values of managing ecotourism and ponds, while the secondary data were in the form of data collected from the results of literature reviews and institutional data. The research population was purposely determined and consisted of two subpopulations, namely (1) communities directly involved in the existence of mangrove ecosystems (ecotourism management) and aquaculture and (2) tourists.

The samples from the first sub-population were taken using a proportionate random sampling method and consisted of a total of 41 people, while the samples from the second sub-population (tourists) were taken using accidental sampling and quota sampling, and consisted of 40 people. Data processing was divided into two parts: (1) the calculation of the total economic value of the mangrove ecosystem and (2) the determination of a prioritized scenario for the management of mangrove ecosystems.

\subsubsection{Total economic value of the mangrove ecosystem}

The total economic value (TEV) of the mangrove ecosystem was calculated with an economic valuation method using Equation 1 (Suparmoko 2006):

$$
\mathrm{TEV}=(\mathrm{DUV}+\mathrm{IUV}+\mathrm{OV})+(\mathrm{EV}+\mathrm{BV})
$$

where TEV is the total economic value, DUV is the direct use value, IUV is the indirect use value, OV is the optional value, $\mathrm{BV}$ is the bequest value, and $\mathrm{EV}$ is the existence value.

The direct use value was calculated using a market price approach. The direct benefits or uses of the mangrove ecosystem were as the provider and producer of fishery and forestry products (Equation 2).

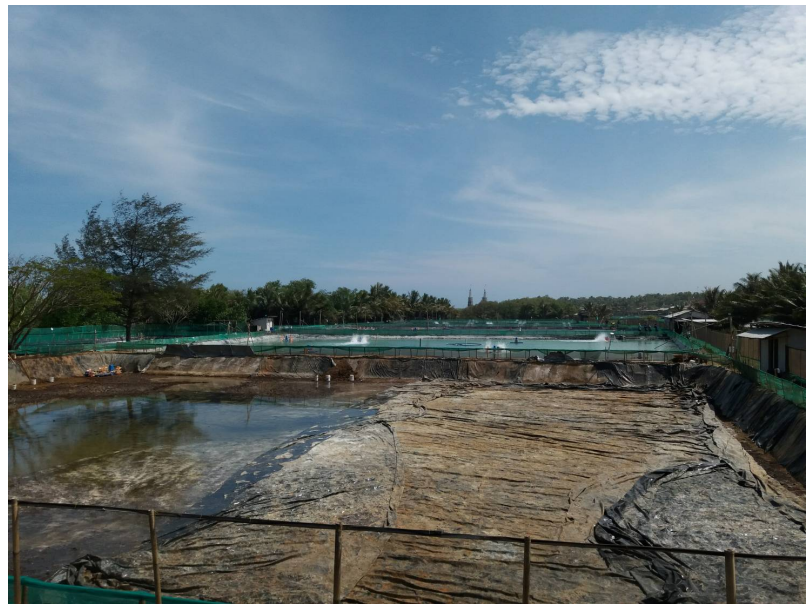

FIGURE 2. The existence of aquaculture threatens the survival of mangroves. Photo taken in 2018. 


$$
\mathrm{DUV} i=(\mathrm{Mp} i \times \mathrm{P} i)-\mathrm{C} i
$$

where DUVi is the direct use of the commodity $i$ (USD/year), Mpi is the market price of the commodity $i$ (USD/ $\mathrm{kg}$ ), $\mathrm{P} i$ is the production of the commodityi ( $\mathrm{kg} /$ year), $\mathrm{C} i$ is the operational costs of the commodity $i$ (USD), and $i$ is the type of the commodity (crab, fish, prawn, or firewood).

Another direct use value of ecotourism was calculated from the actual use value of management using Equation 3 (Ekowarso 2010):

$$
\text { Ecotourism }=\text { Revenue }- \text { Costs }
$$

The direct use of each mangrove ecosystem was calculated using Equation 4 (Suparmoko 2006):

$$
\mathrm{DUV}=\sum \mathrm{DUV} i
$$

where DUV is the direct use and DUVi is the direct use of $i$.

The indirect use of mangrove forest includes its functions as a breakwater, protector of ponds from erosion, and provider of natural feed for mangrove ecosystem biota. The value of its function as a breakwater was calculated based on the analysis of work unit prices issued by the Public Works Research and Development Agency (BALITBANG PU) in 2013 providing the technique data for constructing sinking breakwater with the length $\times$ width $\times$ height dimension of $150 \mathrm{~m} \times 20 \mathrm{~m} \times 5 \mathrm{~m}$, respectively, amounting of USD 0.21 million. The formula for determining the use value as a breakwater is shown in Equation 5 (Tuwo 2011):

$$
\mathrm{IUV}(\text { breakwater })=(L W H) \times D t \times C l \times C
$$

where IUV(breakwater) is the indirect use value of mangroves as breakwaters, L W H is the dimension of breakwater with certain length $\times$ width $\times$ height $\left(\mathrm{m}^{2}\right)$, Dt is the durability of breakwater (years), $\mathrm{Cl}$ is the extent of coastline (m), and $\mathrm{C}$ is the concrete standards (USD).

The indirect use value of mangroves as a protector of ponds from erosion was calculated from the value of lost income from the ponds business, using Equation 6 (Anggraini and Marfai 2017):

$\mathrm{IUV}($ protection of ponds from erosion $)=P p \times M p \times E a$

where IUV(protection of ponds from erosion) is the indirect use value of mangroves as a protector of ponds from erosion, $\mathrm{Pp}$ is the ponds' production per annum (kg/ha/year), $\mathrm{Mp}$ is the market price of prawn (USD/kg), and $\mathrm{Ea}$ is the extent of ponds area $(\mathrm{Ha})$.

The indirect use value of mangrove forests as providers of natural feed for mangrove ecosystem biota was calculated using a substitution cost approach and the market price of the natural feed selling price multiplied by the extent of mangrove forest area. The formula used for calculating this is shown in Equation 7 (Suparmoko 2006):

$$
\mathrm{IUV}(\text { provider of natural feed })=N f \times D y \times F p \times E a
$$

where IUV(providers of natural feeds) is the indirect use as a provider of natural feed for mangrove ecosystem biota,
$\mathrm{Nf}$ is natural feed volume (kg/ha/year), Dy is the number of days in a year, Fp is the feed price (USD/kg), and $\mathrm{Ea}$ is the extent of mangrove forest area (ha).

The indirect value of each mangrove ecosystem was calculated using Equation 8 (Suparmoko 2006):

$$
\mathrm{IUV}=\sum \mathrm{IUV} i
$$

where IUV is the indirect use value and IUVi is the indirect use value of $i$.

The option value of mangrove ecosystems is reflected in the value of biodiversity using the benefit transfer approach, referring to the results of a study conducted by Ruitenbeek (1992) in Bintuni Bay, West Papua, the value of which was USD 15/ha/year. The formula of this is shown in Equation 9 (Suparmoko 2006):

$$
\mathrm{OV}=\mathrm{USD} 15 \text { per ha } \times \text { mangrove area }
$$

The existence value and the bequest value were calculated with the contingent valuation method by directly asking the public about their willingness to pay (WTP) for services generated by a resource and their willingness to engage in preservation efforts (Equation 10) (Tuwo 2011):

$$
\mathrm{EV} \text { or } \mathrm{BV}=\sum \mathrm{EV} \text { or } \mathrm{BV} / \mathrm{n}
$$

where $\mathrm{EV}$ and $\mathrm{BV}$ is the existence and bequest value (USD/year), EV or BVi is the existence and bequest value of respondent $i$, and $n$ is the number of respondents.

\subsubsection{Determining the prioritized scenario for mangrove ecosystem management}

The prioritized scenario of mangrove ecosystem management was determined with the economic valuation method of cost benefit analysis (CBA) by calculating the net present value (NPV) or the current net use value and the benefit cost ratio (BCR) or the ratio between revenue and costs discounted for each management alternative. The equations for determining the NPV and BCR values are shown in Equations 11 and 12 (Suparmoko 2006):

$$
\mathrm{NPV}=\sum \mathrm{B} t-\mathrm{C} t /(1+r) t
$$

$$
\mathrm{BCR}=\sum(B /(1+r) t) /(C /(1+r) t)
$$

where $\mathrm{B} t$ is the gross benefit in year $t, \mathrm{Ct}$ is the gross cost in year $t, n$ is the length of rotation, and $r$ is the interest rate of year $0,1,2,3, \ldots$ year $n$.

The actual land use of ponds and mangrove ecosystems in this study included a pond area 49.20 ha and mangrove ecosystems 12.84 ha in size, according to which alternative scenarios were developed for managing the mangrove ecosystems with spatial considerations that the respective scenario should provide economic value to surrounding communities in the form of natural conservation and aquaculture. The alternative scenarios were as follows (Adrianto 2006):

1. Scenario I, the current actual condition, with a mangrove forest area of 12.84 ha and pond area of 49.0 ha;

2. Scenario II, the condition of mangrove forest and ponds based on the Spatial and Regional Plan (Rencana 
Tata Ruang dan Wilayah [RTRW]) of Kulon Progo Regency with 25.99 ha of mangrove forest and 25.07 ha of ponds;

3. Scenario III, the condition of mangrove forests and ponds with a proportion of 50:50 of the current total area with 31.02 ha of mangrove forest and 31.02 ha of ponds;

4. Scenario IV, the optimal condition of mangrove forest according to RTRW with a fixed area including a mangrove area of $25.99 \mathrm{Ha}$ and ponds of $49.20 \mathrm{Ha}$; and

5. Scenario $\mathrm{V}$, the condition of mangrove forests and ponds with an 80:20 proportion, i.e. 49.43 ha mangrove forest and 28.54 ha ponds.

The prioritized scenario for mangrove ecosystem management was determined based on cost-benefit analysis (CBA) according to which it has the highest economic value and additional considerations based on the assessment criteria of efficiency, equality, and sustainability of each alternative management scenario.

\section{RESULTS AND DISCUSSION}

\subsection{Total economic value of the mangrove ecosystems}

The mangrove forests in the coastal region of Jangkaran Village, Kulon Progo Regency, totalling 12.84 ha in size, are considerably smaller than mangrove forests in other parts of Indonesia, but their functions and benefits are the similar to those of mangrove forests in general. Their potential functions and benefits can be seen and calculated through the total economic value obtained from economic valuations that include their direct use value, indirect use value, option value, existence value, and bequest value.

The direct use value and the indirect use value of the mangrove ecosystem in the coastal area of Jangkaran Village were further divided into several types of benefits or uses. The direct use value included the direct use values of ecotourism, fishery products in the form of crabs, fish, and prawns, and forestry products in the form of firewood. The indirect use value included the value of mangroves as breakwaters, protectors of ponds from erosion, and providers of natural feed for mangrove ecosystem biota. All values were converted from IDR to USD units with an exchange rate of IDR 13,959.00 to the dollar in July 2019.

\subsubsection{Direct use value}

The direct use value of a mangrove ecosystem that can be directly felt economically by the community is the value of ecotourism. The actual use value of ecotourism is defined as the optimal revenue obtained only from entrance tickets and parking fees deducted from the costs incurred in the mangrove ecotourism management (Lestari 2017). The actual use value of the mangrove ecotourism in Jangkaran Village was calculated based on an entrance fee of USD $0.36 /$ ticket with the number of visitors being 140,904/year, from which the total income was calculated to be USD 50,470.66/year minus management costs of USD 21,849.70/year, so that the net value of mangrove ecotourism was USD 28,620.96/year.

The use of mangrove trees for firewood is not supposed to be done on a large scale because they are still at the conservation stage, meaning that their potential utilization is still limited. The use of mangrove trees for firewood can be found in the Wanatirta Ecotourism area, where the mangrove forest has been sufficiently dense. The production of firewood per annum was only around 679 bundles, with a selling price of USD 0.50/bundle. As such, the total revenue from firewood was USD 340.50 with a production cost of USD 0.72 per collection or USD 34.39/year, which included the cost for cigarettes only since it did not incur other costs for producing firewood from mangrove trees. The total actual use value of forestry products in the form of firewood was thus USD 306.11 per annum. The direct use value of forestry products in the form of firewood was relatively small because wood extraction is limited due to conservation considerations (Malik et al. 2015).

The direct use value of fishery products includes prawns, fish, and crabs. Their respective values were 1,086 $\mathrm{kg} /$ year of crabs at a market price of USD $2.65 / \mathrm{kg}, 1,343$ $\mathrm{kg} /$ year of fish at a market price of USD $0.72 / \mathrm{kg}$, and 982 $\mathrm{kg} /$ year of prawns at a market price of USD $4.30 / \mathrm{kg}$. The costs incurred in utilizing fishery products were related to transportation, consumption, and fishing, with an average cost value of USD 2.51. The total cost of producing fishery products was USD 1,353.97/year. The actual use value based on the total revenue minus the total cost of fishery products was USD 6,707.64/year. The total direct use value was USD 57,484.42 (Table 1).

\subsubsection{Indirect use value}

The indirect use value results from the influence of ecosystems on the surrounding environment, which cannot be directly felt by humans (Australian Government Department of the Environment, Water, Heritage, and the Arts 2009). The indirect use value of the mangrove ecosystem in the coastal area of Jangkaran Village included its functions as a breakwater, protector of ponds against erosion, and provider of natural feed for mangrove ecosystem biota.

The indirect use value of the mangrove ecosystem as a breakwater was calculated through the value of breakwater building with an assumed durability of 20 years. The extent of coastline protected by mangrove forests in the study area was around $2,060.82 \mathrm{~m}$. With the use value of the mangrove ecosystem as a breakwater of USD $34,877.70 / \mathrm{ha} /$ year, the total use value of the ecosystem as a breakwater with the current mangrove forest area of 12.84 ha was consequently USD 447,829.69/year. The use value of mangrove forests as breakwaters is influenced by the assumed costs for constructing the breakwater and the length of the coastline (Putranto et al. 2017).

The total area of the ponds located behind the mangrove forests was 23.95 ha was in size. That area can be en-

\begin{tabular}{lll}
\hline \multicolumn{2}{l}{ TABLE } & D \\
\hline No. & Typect use value. & \\
\hline 1 & Ecotourism & Value (USD) \\
2 & Forestry Products & $50,470.66$ \\
3 & Fishery Products & $6,707.64$ \\
4 & Total & $\mathbf{5 7 , 4 8 4 . 4 2}$ \\
\hline
\end{tabular}

TABLE 2. Indirect use value.

\begin{tabular}{llr}
\hline No. & Types of indirect uses & Value (USD) \\
\hline 1 & Breakwater & $447,829.69$ \\
2 & Protection of ponds from erosion & $3,603,051.79$ \\
3 & Provider of natural feed for mangrove & $11,750.91$ \\
& ecosystem biota & \\
4 & Total & $4,062,632.39$ \\
\hline
\end{tabular}


tirely protected from erosion by the mangrove forests. The total revenue generated from prawn farming within the existing area, which was calculated based on an assumption that 1 hectare of pond can produce $10,000 \mathrm{~kg}$ of prawn per production period with a selling price of USD $5.01 / \mathrm{kg}$, was USD 3.60 million/year.

The use value of the mangrove ecosystem as a provider of natural feed for mangrove ecosystem biota was USD $915.18 / \mathrm{ha} /$ year with a feed price of USD $1.00 / \mathrm{kg}$ and volume of litter that can be produced by mangroves as natural feed averaging $2.5 \mathrm{~kg} / \mathrm{ha} /$ day. With a total mangrove area of 12.84 ha, the total use value of the mangrove ecosystem in the study area as a provider of natural feed for the mangrove ecosystem biota was USD 11,679.28/year. The use value of mangrove ecosystems as providers of natural feed are influenced by the extents of mangrove areas and the feed price (Badebaran 2013). The total indirect use value was USD 4.06 million (Table 2).

\subsubsection{Option value}

The option value of the mangrove ecosystem can be seen in the value of mangrove ecosystem biodiversity. Biodiversity value is the value of all living things that exist on earth including genetic diversity and the ecosystems it forms (Kusmana 2015). The biodiversity value of the mangrove ecosystems was calculated based on research by Ruitenbeek (1992), and amounted to USD 15/ha/year or equivalent to USD $15.31 /$ ha/year based on exchange rates in July 2019 , i.e. IDR $13,959.00$ to the dollar.

The biodiversity value from the Ruitenbeek study can be applied to all mangrove forests in Indonesia provided that the mangrove ecosystem is preserved naturally and has an important influence ecologically. Therefore the biodiversity value in the coastal area of Jangkaran Village with an area of 12.84 ha was USD 196.63/year.

\subsubsection{Existence value}

The existence value of mangrove forests is calculated from the WTP value, i.e. the willingness of the community to

TABLE 3. Total economic value.

\begin{tabular}{llc}
\hline No. & Types of economic values & Value (USD) \\
\hline 1 & Direct use value & $57,484.42$ \\
2 & Indirect use & $4,062,632.39$ \\
3 & Option value & 196.63 \\
4 & Existence value & $756,962.35$ \\
5 & Bequest value & $1,855,869.04$ \\
6 & Total & $\mathbf{6 , 7 3 3 , 1 4 4 . 8 2}$ \\
\hline
\end{tabular}

TABLE 4. Components of benefits and costs for managing ecotourism and ponds.

\begin{tabular}{llcc}
\hline No. & Parameter & Ecotourism & Ponds \\
\hline 1 & Area (ha) & 12.84 & 49.20 \\
2 & $\begin{array}{l}\text { Total management benefits } \\
\text { (USD/year) }\end{array}$ & $50,470.66$ & $7,401,676.34$ \\
3 & $\begin{array}{l}\text { Management benefits } \\
\text { (USD/ha/year) }\end{array}$ & $3,930.74$ & $150,433.85$ \\
4 & $\begin{array}{l}\text { Total management costs } \\
\text { (USD/year) }\end{array}$ & $21,849.70$ & $2,719,378.81$ \\
5 & $\begin{array}{l}\text { Management costs } \\
\text { (USD/ha/year) }\end{array}$ & $1,701.69$ & $55,269.46$ \\
\hline
\end{tabular}

pay for the services provided by the environment. Based on interviews with surrounding communities and tourists, the average existence value in the study area was USD 10.06/year for the community and USD 5.24/year for tourists. This indicates that the existence value of mangrove forests for the community was emphasized on the function of mangrove forests, which can be developed as tourist areas as well as for their physical and biological functions, while for the tourists the existence value was derived from the natural beauty presented by mangrove forests.

The total existence value from the community with a population of 1,825 inhabiting Pasir Kadilangu and Pasir Mendit Hamlets was as much as USD 18,388.87/year, while from the tourists totaling 140,904 visitors/year, it was USD $738,594.97 /$ year, resulting in the total existence value both from the surrounding community and the tourists being USD 756,962.35.

\subsubsection{Bequest value}

The bequest value of the mangrove ecosystem was also calculated from the WTP value, which emphasizes the respondents' willingness to pay for the preservation of mangrove ecosystems so that the functions and benefits can be felt by future generations. The high value given by the respondents indicates a high public awareness of environmental sustainability. The average value of the surrounding community's WTP per year was USD 162.146, while that of tourists was USD 13.02.

The average annual WTP for the bequest value of the community with a population of 1,825 people was USD $21,199.02$, while the average annual WTP for the bequest value of tourists totalling 140,904 per year was USD 1.83 million/year, together resulting in a total bequest value of USD 1.86 million.

\subsubsection{Total economic value}

The total economic value of the mangrove ecosystem in the coastal area of Jangkaran Village was USD 6.73 million (Table 3). The calculated use value may represent the overall functions and benefits of the mangrove ecosystem in the coastal area of Jangkaran Village. The value that contributes most to the total economic value of this mangrove ecosystem is the indirect use value, i.e. $60 \%$, with a total value of USD 4.06 million (Figure 3).

The high indirect use value indicates that the mangrove ecosystem provides substantial services to the surrounding environment, especially in terms of physical aspects in the form of sustaining environmental conservation because direct uses are not carried out optimally in this study area, so

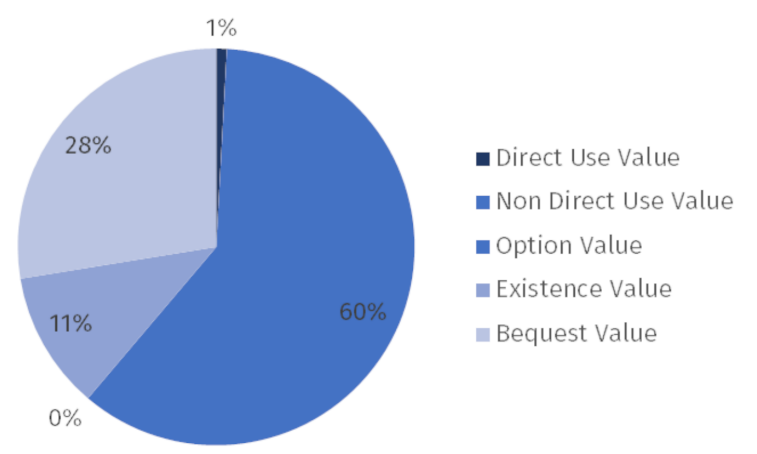

FIGURE 3. Contributions of different values to the total economic value of the mangrove ecosystem. 
that the indirect use gives a greater contribution to the total economic value. The magnitude of the indirect benefit value was influenced by the extent of the mangrove forest area in that the wider the mangrove forests, the greater the indirect benefits provided so that the total economic value will be greater as well, and vice versa (Putranto et al. 2017).

\subsection{Prioritized scenario for mangrove ecosystem manage- ment}

Coastal area resources are multi-use and multi-source in nature, enabling alternative management approaches to be carried out on mangrove ecosystems with considerations of technical aspects, development priorities, ecological aspects, and the sociopolitics of local communities in the mangrove ecosystem. The alternatives can be in the form of conservation areas or multipurpose areas. The existence and development of mangrove forests and ponds can be carried out side-by-side provided that that the proportion of both are ideal, so that instead of adversely affecting each other they can positively influence each other, both economically and environmentally.

The total economic value of the mangrove ecosystems and the cost-benefit value of managing them both in the forms of ecotourism and pond farming are currently used as the basis for assessing mangrove ecosystem allocation efficiencies in various alternative management scenarios that not only prioritize economic interests, but take ecological aspects into account, as well.

All the alternative scenarios developed in this study were assumed to represent what policies should be applied to the mangrove ecosystem of Jangkaran Village, based on the changes made in the area that affect the economic and environmental values. The analysis results of the current benefit and costs components of ecotourism and prawn farming management, occurring in areas of 12.84 ha of mangrove forest and 49.20 ha of prawn ponds, can be used to calculate the cost and benefit values per hectare (Table 4).

The benefit and costs of managing mangrove ecotourism were found to be USD 3,930.74/ha and USD 1,701.69/ha, respectively, while the benefit and costs of managing prawn ponds were USD 150,433.85/ha and USD $55,269.46 /$ ha, respectively. The value of other uses of mangrove forests outside ecotourism was USD 6.68 million/year or USD $520,457.49 / \mathrm{ha} /$ year. The value of benefits and costs per hectare were multiplied by the area in each scenario.

The calculation of costs for pond farming is not only based on the costs of investment, production, and maintenance actually incurred in the field, but also takes environmental costs of the existence of ponds into consideration. The environmental cost was calculated by assuming that the extent of pond area that exceeds the ideal proportion of ponds area and mangrove area may affect or, more specifically, reduce the use of mangrove forest, the value of which is equal to the percentage of the area that exceeds the ideal proportion. The ideal proportion of mangrove area and pond area is 50:50 (Putranto et al. 2017). The total net use value and the total benefit and costs of ecotourism, prawn ponds, and other uses of the mangrove ecosystem are shown in Table 5.

The management of mangrove ecosystems and the surrounding environment based on each alternative scenario was then assessed through business feasibility criteria of the net present value (NPV) with a discount rates of $3.43 \%$ (based on real discount rates as of March 2019) and discount rate of $15 \%$, which is the ideal discount rate for economic analysis of resource use and the comparison between the benefit and costs of management through the benefit cost ratio (BCR). The results of management scenario assessment by NPV and BCR are shown in Table 6 .

As indicated in Table 5, among alternative scenarios I to $\mathrm{V}$, Scenario $\mathrm{V}$ had the greatest value in terms of total profit resulting from mangrove forest management and other benefits from the existence of mangrove forest. This is influenced by the proportion of other benefits of mangrove forests, which also had the highest value so that Scenario $V$ had the highest economic and environmental values compared with those of the other alternative scenarios.

The high benefit value of Scenario V was strongly influenced by the high value of other benefits from the existence of mangrove ecosystems, which are affected by the

TABLE 5. Use values of mangrove ecosystem management.

\begin{tabular}{|c|c|c|c|c|c|c|}
\hline No. & Alternative scenarios & $\begin{array}{l}\text { Total benefit (USD } \\
\text { million/year) }\end{array}$ & $\begin{array}{l}\text { Total costs (USD } \\
\text { million/year) }\end{array}$ & $\begin{array}{c}\text { Total profit (USD } \\
\text { million/year) }\end{array}$ & $\begin{array}{l}\text { Total benefit of other } \\
\text { uses of mangrove } \\
\text { ecosystem (USD } \\
\text { million/year) }\end{array}$ & $\begin{array}{l}\text { Total profit of mangrove } \\
\text { forest management } \\
\text { and existence (USD } \\
\text { million/year) }\end{array}$ \\
\hline 1 & Alternative Scenario I & 7.45 & 4.68 & 2.77 & 4.74 & 7.52 \\
\hline 2 & Alternative Scenario II & 3.87 & 1.43 & 2.44 & 13.53 & 15.97 \\
\hline 3 & Alternative Scenario III & 4.79 & 1.77 & 3.02 & 16.15 & 19.17 \\
\hline 4 & Alternative Scenario IV & 7.50 & 4.79 & 2.71 & 11.50 & 14.21 \\
\hline 5 & Alternative Scenario V & 2.06 & 0.77 & 1.29 & 25.83 & 27.12 \\
\hline
\end{tabular}

TABLE 6. Cost-benefit analysis results for different alternative scenarios of mangrove ecosystem management.

\begin{tabular}{|c|c|c|c|c|}
\hline \multirow[t]{2}{*}{ No. } & \multirow[t]{2}{*}{ Alternative scenarios } & \multicolumn{2}{|c|}{ Net present value (USD million/25 years) } & \multirow[t]{2}{*}{ Benefit cost ratio } \\
\hline & & Discount rate $=3.43 \%$ & Discount rate $=15 \%$ & \\
\hline 1 & Alternative Scenario I & 46.05 & 17.92 & 1,593 \\
\hline 2 & Alternative Scenario II & 40.58 & 15.79 & 2,709 \\
\hline 3 & Alternative Scenario III & 50.18 & 19.53 & 2,710 \\
\hline 4 & Alternative Scenario IV & 45.02 & 17.52 & 1,566 \\
\hline 5 & Alternative Scenario $\mathrm{V}$ & 21.45 & 8.35 & 2,677 \\
\hline
\end{tabular}


extent of mangrove forest area. The management area of the Scenario V consists of $49.63 \mathrm{Ha}$ of mangrove forest and $12.41 \mathrm{Ha}$ of ponds, indicating that there is a quite significant reduction in the pond area, something that will in turn affect the surrounding community because of the decreasing economic value that can be directly felt by the community. This can be seen from the value of management feasibility for Scenario V, which was the lowest among the alternative scenarios (Table 6), while the value of other benefits from the existence of mangrove forests cannot be directly felt by the community in the economic sense. This would likely lead to various pros and cons since pond farming is still of interest to the south coast community due to the high profits it generates, as well as because it has been a source of community income in recent years.

Another alternative scenario that had the highest value of management feasibility, with a relatively high value of other benefits from the existence of mangrove forests, was Scenario III (Tables 5 and 6). scenario III has an ideal proportion of mangroves and ponds areas (i.e. 50:50, or 31.02 ha each), which means that 50 percent of the current total area is used respectively for mangrove forests and ponds. The reduction in pond area in the Scenario III is not too large, while on the other hand there is an increase in the area designated for mangrove forest. This means that there are no additional environmental costs in this scenario, resulting in a net benefit from the management of mangrove ecosystem that may be obtained optimally, both economically and environmentally.

According to Scenario III, the net profit of mangrove ecosystem management in the form of ecotourism and pond farming is USD 3.02 million/year. With rough calculations, if the net profit from ecotourism, amounting to USD 69,147.48/ year, is divided by 63 people involved in ecotourism management, each family would get an additional profit of USD 91.46/month, whereas with a net profit of USD 2.95 million/year from managing ponds of 31.02 ha, pond farmers would earn USD 3,172.26/1000 $\mathrm{m}^{2}$ in each production period.

By considering the economic criterion of efficiency which is based on CBA, the social criterion of equality, which is based on income equalization, and sustainability, which is based on area changes, the Scenario III can be used as the prioritized scenario in the management of mangrove ecosystems in the coastal area of Jangkaran Village, Kulon Progo Regency (Figure 4).

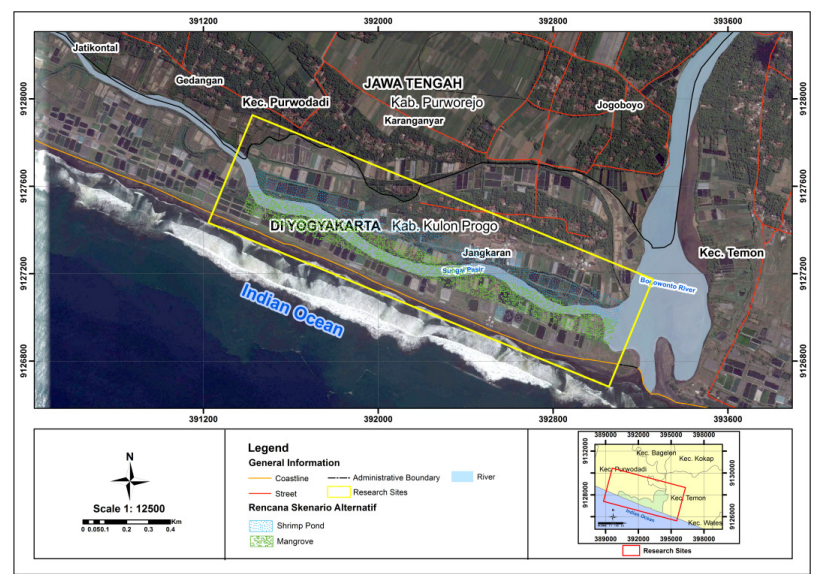

FIGURE 4. Map of the application of the prioritized scenario for mangrove ecosystem management in the coastal area of Jangkaran Village, Kulon Progo Regency.

\section{CONCLUSIONS}

The total economic value of the mangrove ecosystem in the coastal area of Jangkaran Village, Kulon Progo Regency, was found to be USD 6.73 million/year, with a direct use value of USD 57,484.42/year (0.9\%), an indirect use value of USD 4.06 million/year (60.3\%), an option value of USD 196.63/year (0.003\%), an existence value of USD $756,962.35$ /year (11.2\%), and a bequest value of USD 1.86 million/year (27.6\%). While the indirect use value made the greatest contribution, indicating that the mangrove ecosystems provides great services to environmental sustainability, this contribution cannot be felt directly by the community in an economic sense.

Based on the results of economic valuations, Scenario III, with an ideal proportion of mangrove forest area to pond area (50:50), can be prioritized for the management of the mangrove ecosystem in the coastal area of Jangkaran Village. This scenario should have the most benefit, both economically and ecologically, because it would provide the greatest economic profit and allow for environmental preservation in terms of ecological aspects, enabling the management to be carried out optimally and sustainably.

\section{ACKNOWLEDGMENTS}

The authors would like to thank the Directorate of Research of Universitas Gadjah Mada for funding the research through "Rekognisi Tugas Akhir (RTA) 2018." The authors also express their appreciation to the Government of Jangkaran Village and especially to the mangrove forest managing community in Pasir Kadilangu Sub-village and Pasir Mendit Sub-village.

\section{AUTHORS' CONTRIBUTIONS}

DA contributed to the preparation of research concepts, data processing, and analysis. RH contributed to the maturation of concepts and revisions, and provided input on data processing and analysis.

\section{REFERENCES}

Adrianto L. 2006. Pengantar penilaian ekonomi sumberdaya pesisir dan laut [Introduction to the economic assessment of coastal and marine resources]. Bogor: Pusat Kajian Sumberdaya Pesisir dan Lautan IPB.

Anggraini DD, Marfai MA. 2017. Analisis jasa ekosistem mangrove dalam mengurangi erosi pantai di sebagian pesisir Kecamatan Rembang, Kabupaten Rembang [Analysis of mangrove ecosystem services in reducing coastal erosion in some coastal areas Rembang District, Rembang Regency]. J Bumi Indones. 6(3):85-93.

Australian Government Department of the Environment, Water, Heritage, and the Arts. 2009. Ecosystem services: key concepts and applications. Occasional paper no 1. Canberra: Australian Government Department of the Environment, Water, Heritage, and the Arts. http://www.environment.gov.au/biodiversity/public ations/ecosystem-services-key-concepts-and-appli cations.

Badebaran DWK. 2013. Model valuasi ekonomi sebagai dasar untuk rehabilitasi kerusakan hutan mangrove di wilayah pesisir Kecamatan Kwandang, Kabupaten Gorontalo Utara, Provinsi Gorontalo [Economic valuation model as a basis for rehabilitation of damage to mangrove forests in coastal areas Kecamatan Kwan- 
dang, District North Gorontalo, Gorontalo Province] [dissertation]. [Yogyakarta]: Universitas Gadjah Mada.

Djohan TS. 2000. Prospek pengembangan mangrove di pantai selatan Yogyakarta [prospects for developing mangroves on the south coast of Yogyakarta]. Rehabilitasi hutan mangrove melalui pemberdayaan masyarakat dalam rangka otonomi daerah [Mangrove forest rehabilitation through community empowerment in the context of regional autonomy]. Yogyakarta: Pusat Pengembangan Rehabilitasi Mangrove INSTIPER.

Ekowarso. 2010. Nilai ekonomi lingkungan dan faktorfaktor yang mempengaruhi permintaan objek wisata air panas pawan di Kabupaten Rokan Hulu (pendekatan biaya perjalanan) [The economic value of the environment and the factors affecting demand for pawan hot spring attractions in Rokan Hulu Regency (travel cost approach)]. J Ekon. 18(3):103-200.

Kridalaksana A, Subiyanto, Suryanto A. 2014. Pengelolaan tambak dan mangrove di area pertambakan di Desa Mororejo, Kecamatan Kaliwungu, Kabupaten Kendal [Management of ponds and mangroves in the area of ponds in Mororejo Village, Kaliwungu District, Kendal District]. Manage Aquat Res. 3(2):148-156.

Kusmana C. 2015. Keanekaragaman hayati (biodiversitas) sebagai elemen kunci ekosistem kota hijau [Biodiversity as a key element of a green city ecosystem]. Prosiding Seminar Nasional Masyarakat Biodiversity Indonesia. p. 1747-1755. doi:10.13057/psnmbi/m010801.

Lestari NB. 2017. Implementasi travel cost method dalam menghitung nilai ekonomi ekowisata hutan mangrove Desa Pasar Banggi, Kabupaten Rembang, Jawa Tengah [Implementation of travel cost method in calculating the economic value of mangrove forest ecotourism in Pasar Banggi Village, Rembang Regency, Central Java] [dissertation]. [Surabaya]: Universitas Brawijaya.

Malik A, Fensholt R, Mertz O. 2015. Economic valuation of mangroves for comparison with commercial aquaculture in South Sulawesi, Indonesia. Forests. 6(9):30283044. doi:10.3390/f6093028.

Murtini S, Kuspriyanto, Kurniawati A. 2018. Mangrove area development strategy Wonorejo as ecotourism in Surabaya. J Phys: Conf Ser. 953:012174. doi:10.1088/17 42-6596/953/1/012174.

Putranto S, Zamani NP, Sanusi HS, Riani E, Fahruddin A. 2017. Valuasi ekonomi sumberdaya hutan mangrove di Kabupaten Banggai dan Banggai Kepulauan, Sulawesi Selatan [economic valuation of mangrove forest resources in Banggai Regency and Banggai Islands, South Sulawesi]. J Ilmu dan Teknol Kelaut Trop. 9(2):645-656.

Ruitenbeek HJ. 1992. Mangrove management: an economic analysis of mangrove option With a focus on Bintuni Bay Irian Jaya. Jakarta: EMDI Environment Report.

Statistics Indonesia. 2017. Statistik sumberdaya laut dan pesisir [Statistics of marine and coastal resources]. Jakarta: Statistics Indonesia.

Suparmoko M. 2006. Panduan dan analisis valuasi ekonomi sumberdaya alam dan lingkungan (konsep, metode perhitungan, dan aplikasi) [Guidelines and economic valuation analysis of natural resources and the environment (concepts, calculation methods, and applications)]. Yogyakarta: BPFE UGM.

Tuwo A. 2011. Pengelolaan ekowisata pesisir dan laut [Management of coastal and marine ecotourism]. Surabaya: Brilian Internasional. 